\title{
Mental Illness: A Suspect Classification?
}

In drafting a statute legislators delineate categories of persons favored or disfavored by the operation of the law. Depending upon their assessment of the costs and benefits of greater individualization, lawmakers are more or less precise in identifying those people having the characteristic or characteristics relevant in terms of effectuating the purposes of the law. The classification chosen, therefore, is typically imperfect but made nonetheless because, in the legislator's judgment, it will serve the legislative purposes well enough; the increased benefits promised by a more discriminating classification, on the other hand, would be outweighed by the added costs of establishing and administering a more precise classification.

In light of these practical considerations of legislative classification, it is not surprising that legislators have often employed the class of mentally ill persons ${ }^{1}$ as a convenient shorthand. By equating mental illness with such characteristics as dangerousness, irrationality, dependence, and irresponsibility, the lawmaker has immensely simplified many classification problems. If the legislature wishes to keep guns out of the hands of dangerous persons, for example, it can

1. "Mental illness" has been variably defined in both medical and legal circles. A discussion of the definitional problems attending "mental health" offers insight into the bases of disagreement among psychiatrists:

Definitions obviously vary with the perspective of the definers, the point of reference used, and the values considered important. Thus, the psychoanalytic perspective focuses on the intrapsychic life of the individual. . . . Here the value is awareness of unconscious motivations and self-control based upon these insights. The interpersonal frame of reference, on the other hand, is more concerned with the functioning of individuals in interpersonal situations .... [This frame] places major value on effective and efficient social functioning. The social relatedness perspective . . . focuses on the individual's relationship with the larger social cnvironment. - . Here the values are humanism, individualism, freedom and rationality.

Schwartz \&. Schwartz, Mental Health: The Concept, 10 INT'L ENCYc. Soc. Scr. 215, 210 (D. Sills ed. 1968) (emphasis in original); cf. Dodd v. Hughes, 81 Nev. 43, 46, 398 P.2d 540,542 (1965). The legal definitions of "mental illness" codified by the individual states also vary widely. For a comprehensive listing, see THE MENTALly Disabled AND THE LAW 66-71 (S. Brakel \& R. Rock eds. 1971) (Table 3.1) [hereinafter cited as BRAKEL \& Rock]. Variable application of similar laws is virtually assured, moreover, because these legal definitions are typically "vague and ambiguous." See Hearings on the Constitutional Rights of the Mentally Ill Before the Subcomm. on Constitutional Rights of the Senate Comm. on the Judiciary, 87th Cong., lst Sess. 193 (1961) (statement of Professor Hugh A. Ross). See, e.g., D.C. CODE ANN. \$ 21.501 (1967): "[M]ental illness' means a psychosis or other disease which substantially impairs the mental health of a person." Despite this lack of consensus on the meaning of "mental illness," legislators have readily correlated the mental illness label with stereotypical characteristics for purposes of legislative classification. See pp. 1237-38, 1260-68 infra. 
single out the mentally ill as a dangerous class and thereby secure a rather rough but inexpensive approximation of its goal. ${ }^{2}$ Or legislators may translate their concern that people be treated by competent doctors into a blanket prohibition against the award of medical licenses to the mentally ill. ${ }^{3}$ Promoting informed exercise of the franchise, securing a jury of one's peers, minimizing marital disharmony-these legislative concerns and numerous others with which few persons may quarrel in principle have become the source of laws which classify on the basis of mental illness to the great detriment of the mentally ill.4

Civil commitment statutes, however-the most familiar employment of the mental illness classification and the usual source of the finding of mental illness central to the administration of the above statutes-appear to disadvantage the mentally ill for reasons other than a cost-benefit determination of the advantages of greater individualization in classification. For these laws typically require a present adjudication of dangerousness or need of treatment and of mental illness: ${ }^{5}$ At least in principle, therefore, the latter cannotas it indeed can with licensing or voting laws-supply the characteristic relevant to the legislative goal. Why use the classification at all, then?

This Note seeks to answer that question and to raise others fundamental to the validity of laws classifying on the basis of mental illness by inquiring into the rationale underlying the equal protection doctrine of suspect classifications. More specifically, it will argue that classification on the basis of mental illness is constitutionally "suspect" and therefore warrants the standard of review traditionally given suspect classifications. After establishing the theoretical basis for this proposition, the Note will examine the consequences of treating mental illness as a suspect classification. Finally, it will, in recognition of recent developments in equal protection theory, attempt to demonstrate that declaring mental illness a suspect classification would be consistent with the Burger Court's apparent conception of the judiciary's appropriate role in reviewing legislative decisions.

2. See, e.g., 18 U.S.C. $\$ 922(\mathrm{~h})(4)(1970)$.

3. See, e.g., ARK. StAT. ANN. $\$ 72-613$ (11) (Supp. 1969). For a complete listing of similar laws, see BRAKEL \& Rock, supra note 1, at $326-32$ (Table 9.3).

4. See pp. 1267-68 infra.

5. See, e.g., Cat. WhLF. \& INST'Ns CODE $\S 5150$ (West 1972). See generally Brakel \& Rock, supra note 1, at 72-76 (Table 3.2). 


\section{Traditional Treatment of the Question}

\section{A. Standards of Judicial Review under the Equal Protection Clause-Generally}

The significance of regarding classifications by mental illness as suspect becomes apparent only in the context of a broader discussion of equal protection doctrine. Basically, the Equal Protection Clause of the Constitution ${ }^{6}$ requires each state to treat persons equally. This does not mean that a state lawmaker must regard all citizens as the same, ignoring their diversity; state laws are expected to take differences among the citizenry into account. Rather, this clause's demand of equality is a mandate to give equal treatment to persons similarly situated-or, from another perspective, to treat people differently only on the basis of differences among them relevant to effectuating lawful legislative purposes. In general, the Supreme Court, as ultimate arbiter of state compliance with the Equal Protection Clause, leaves state legislatures free to classify imperfectly to serve legitimate goals as long as the classification bears a rational, or plausible, relation to those goals. ${ }^{7}$ The persistence of the laws noted above employing the mental illness classification to secure legislative ends witnesses the leeway typically allowed in legislative classification.

But judicial review of the legislative decision is not always as relaxed as the survival of these laws singling out the mentally ill may imply. If the Court determines that a statute either deprives some persons of a "fundamental interest" 8 or employs a "suspect classification" 9 in creating categories of persons favored or disfavored by its operation, the Court will not tolerate merely a rational connection

6. "No State shall ... deny to any person within its jurisdiction the equal protection of the laws." U.S. CoNsT. amend. XIV, $\$ 1$.

7. Railway Express Agency v. New York, 336 U.S. 106 (1949), exemplifies the rational relation test. Under review was a New York City traffic regulation that allowed business vehicle owners to carry on their vehicles advertisements of their own business but not advertisements of the businesses of others. Accepting as the legislative goal the promotion of traffic safety, the Court held the classification valid on the ground that the local authorities may well have concluded that those who advertise their own wares on their trucks do not present the same traffic problem [as those who advertise others' wares] in view of the nature or extent of the advertisement which they use.

Id. at 110. See McGowan v. Maryland, 366 U.S. 420 (1961); Morey v. Doud, 354 U.S. 457 (1957); Williamson v. Lee Optical Co., 348 U.S. 483 (1955). See generally Tussman \& tenBroek, The Equal Protection of the Laws, 37 CaLIF. L. Rev. 341 (1949).

8. See, e.g., Shapiro v. Thompson, 394 U.S. 618 (1969) (interstate travel); Harper v. Virginia Bd. of Elections, 383 U.S. 663 (1966) (voting); Griffin v. Illinois, 351 U.S. 12 (1956) (equal access to appellate review in criminal cases).

9. See, e.g., Graham v. Richardson, 403 U.S. 365 (1971); Johnson v. Virginia, 373 U.S. 61 (1963); Brown v. Board of Educ., 347 U.S. 483 (1954); Korematsu v. United States, 323 U.S. 214 (1944). 
between the legislative goal and the classification chosen to implement it. Rather, it will subject the law under review to "strict scrutiny," invalidating it unless the classification appears calculated to serve the legislature's end with a far higher degree of precision than ordinarily required. And indeed, almost without exception, the Court's announcement that strict scrutiny is applicable has signaled an ultimate finding that the law under review is unconstitutional. ${ }^{10}$

In the 1971 term the Court evolved yet a third standard of review in equal protection cases. On occasion, although the Court suggested that it was demanding only a rational connection between the legislative classification and goal, it struck down laws probably valid under the traditional rationality test.11 And apparently this new rationality standard required something less than the precision in classification needed to survive strict scrutiny: On the one hand, the Court upheld "rational" classifications which would probably be invalid under a strict scrutiny standard ${ }^{12}$ and, on the other hand, the Court continued to invoke the latter standard explicitly in some cases. ${ }^{13}$

From the perspective of a plaintiff challenging the constitutionality of mental illness classifications, therefore, the optimal result would be to trigger the strict scrutiny standard of review. The new "slidingscale"1* rationality test may suffice to bring about the desired result, but the uncertainties of review under this standard are already amply documented, especially in the wealth classification area. ${ }^{15}$ Strict

10. The exceptions are Tancil v. Woolls, 379 U.S. 19 (1964); Korematsu v. United States, 323 U.S. 214 (1944); Hirabayashi v. United States, 320 U.S. 81 (1943); cf. Lee v. Washington, 390 U.S. 333, 334 (1968) (Black, Harlan \& Stewart, IJ., concurring).

11. E.g., James v. Strange, 407 U.S. 128 (1972); Eisenstadt v. Baird, 405 U.S. 438 (1972). See Gunther, Foreword: In Search of Evolving Doctrine on a Changing Court: $A$ Model for a Newer Equal Protection, 86 HARv. L. REv. 1, 33 (1972):

There is no doubt that the intensity of review in these... cases is higher than that associated with the extremely deferential old equal protection. In all of the cases, the Court was less willing to strain for conceivable justifications, less ready to hypothesize imaginable facts that might underlie questionable classifications, less inclined to tolerate substantial over- and underinclusiveness in deference to legislative flexibility.

Compare Reed v. Reed, 404 U.S. 71 (1971), with Goesaert v. Cleary, 335 U.S. 464 (1918).

12. E.g., Jefferson v. Hackncy, 406 U.S. 535 (1972); Lindsey v. Normet, 405 U.S. 56

(1972); Richardson v. Belcher, 404 U.S. 78 (1971). See Gunther, supra note 11, at 13-14.

13. E.g., Chicago Police Dep't v. Mosley, 408 U.S. 92 (1972); Dunn v. Blumstein, 405

U.S. 330 (1972); Bullock v. Carter, 405 U.S. 134 (1972).

14. See Gunther, supra note 11 , at 17-18.

15. See San Antonio Independent School Dist. v. Rodriguez, 411 U.S. 1 (1973); James v. Strange, 407 U.S. 128 (1972); Jefferson v. Hackney, 406 U.S. 535 (1972); Lindsey v. Normet, 405 U.S. 56 (1972); Richardson v. Belcher, 404 U.S. 78 (1971); James v. Valtierra, 402 U.S. 137 (1971). Had the Warren Court explicitly declared wealth classifications suspect-rather than simply intimate the like, see, e.g., Harper v. Virginia Bd. of Elections, 383 U.S. 663,668 (1966)-those recent cases that were decided adversely to the 
scrutiny, on the other hand, would be a virtual guarantee of success. ${ }^{10} \mathrm{~A}$ declaration that the classification is suspect would obviate the necessity for case-by-case decisionmaking regarding the applicable standard of review; strict scrutiny would henceforth be the test for all mental illness classifications. ${ }^{17}$

\section{B. Some Attempts to Elucidate the Criteria Informing Suspect Clas- sifications: Implications for Classification by Mental Illness}

The Supreme Court has indicated, with varying degrees of explicitness, that certain classifications are ${ }^{18}$ or are not ${ }^{19}$ suspect. It has not, however, articulated the criteria used in deciding whether or not a classification is suspect. McLaughlin $v$. Florida, ${ }^{20}$ in which the Court invalidated a law prohibiting cohabitation by unmarried biracial couples, contains perhaps the clearest statement by a majority of the Court on the matter. Mr. Justice White, writing for the Court, emphasized that:

plaintiffs (i.e., all of the above except James v. Strange, and Lindsey v. Normet in part) would almost certainly have gone the other way.

In the sex classification cases, Cleveland Bd. of Educ. v. La Fleur, 94 S. Ct. 791 (1974); Frontiero v. Richardson, 411 U.S. 677 (1973); Reed v. Reed, 404 U.S. 71 (1971), the Court has uniformly struck down the law or practice under review as irrational. Nevertheless, although the Court's failure to declare classification by sex suspect has made no difference to the outcome in these cases, it may well make the crucial difference in a future sex classification, for the Court will be free to tolerate imperfection in classification provided it meets the minimal rationality standard.

16. In his celebration of sliding-scale rationality as a check on legislative choice of means, Professor Gunther points out that the Court tolerates imperfect classifications under this standard where it recognizes "legitimate demands for legislative flexibility." Gunther, supra note 11 , at $47-48$. Since this "legitimacy" would seem to be nothing more at this point than a conclusory label affixed by the Court-i.e., not an objectively verifiable quality-Professor Gunther has obscured, but not really refuted, the existence of unfettered discretion on the Court's part in applying a sliding-scale test.

17. The repercussions throughout the nation's judicial system after the Court declares a classification to be suspect should not be overlooked. The Court's failure to make such a declaration about classification by sex, for example, leaves state and federal courts broad discretion in reviewing sex classifications, the Court's consistency in such matters thus far notwithstanding.

18. See Graham v. Richardson, 403 U.S. 365 (1971) (alienage); Bolling v. Sharpe, 347 U.S. 497 (1954) (race); Hirabayashi v. United States, 320 U.S. 81 (1943) (nationality).

19. See Dandridge v. Williams, 397 U.S. 471 (1970) (wealth). Although the Court on one occasion strongly intimated that illegitimacy of birth is not suspect, Labine v.
Vincent, 401 U.S. 532 (1971), it has since appeared to have withdrawn from its earlier pronouncement. See Weber v. Aetna Cas. \&. Sur. Co., 406 U.S. 164 (1972). Indeed, in Weber the Court went far in limiting Labine to its facts as a manifestation of the special considerations obtaining in the estates field, id. at 170-72, and unequivocally approved, id. at $167-70$, the authority of Levy v. Louisiana, 391 U.S. 68 (1968), whose intimation of the suspect status of illegitimacy Labine had appeared to dispel.

The Court studiously avoided deciding whether sex is suspect in Reed v. Reed, 404 U.S. 71 (1971), where it struck down as "irrational" a law favoring men over women in estate administration contests. Subsequent cases have also left the issue open, though in Frontiero v. Richardson, 411 U.S. 677 (1973), four members of the Court explicitly subscribed to sex's suspect status.

20. 379 U.S. 184 (1964). 
[W]e deal here with a classification based upon the race of the participants, which must be viewed in light of the historical fact that the central purpose of the 14th Amendment was to eliminate racial discrimination emanating from official sources in the States. This strong policy renders racial classifications "constitutionally suspect," Bolling v. Sharpe, 347 U.S. 497, 499, . . . and subject to the "most rigid scrutiny," Korematsu v. United States, 323 U.S. 214, 216, . . . and "in most circumstances irrelevant" to any constitutionally acceptable legislative purpose, Hirabayashi v. United States, 320 U.S. $81,100 \ldots .21$

The allusion to a "central purpose" criterion would seem to constitute a rather unequivocal explanation by the Court of its understanding of what makes a classification suspect. And if this is indeed the test for suspect classifications, there should be little question that classification by mental illness is outside of its scope.

The very next sentence in the quoted portion of McLaughlin, however, warns against reading its preceding statement as an announcement of a central purpose theory, for the Court cites Korematsu and Hirabayashi, cases affirming that classifications based on nationality are suspect. A contradiction is thus apparent: Since the history of the Fourteenth Amendment indicates that its framers' focus was on that group whose subjugation had only recently fueled a major war between the states of the Union-the black race-and not upon ancestral minorities, ${ }^{22}$ the Court cannot consistently adhere to a central purpose theory and simultaneously reiterate its approval of earlier cases holding nationality to be a suspect classification. Similarly irreconcilable with a central purpose criterion, furthermore, is the Court's subsequent addition of classification on the basis of alienage to the suspect circle. ${ }^{23}$ If mental illness is not a suspect classification, the central purpose argument hardly seems an adequate explanation. ${ }^{24}$

On the other hand, this theory may not be as insubstantial as the preceding discussion makes it out to be. Thus one might construe the theory to embrace classifications by nationality and alienage because they are "like" race. ${ }^{25}$ Whether mental illness is enough

21. Id. at 191-92.

22. See Slaughter-House Cases, 83 U.S. (16 Wall.) 36, 70-72 (1873). See also Strauder v. West Virginia, 100 U.S. 303, 307-08 (1880).

23. See Graham v. Richardson, 403 U.S. 365 (1971).

24. The most recent affirmation of the central purpose criterion belongs to Mr. Justice Rehnquist. See Sugarman v. Dougall, 413 U.S. 634, 649 (1973) (Rehnquist, J., dissenting).

25. Cf. San Antonio Independent School Dist. v. Rodriguez, 411 U.S. 1, 61 (1973) (Stewart, J., concurring); Harper v. Virginia Bd. of Elections, 383 U.S. 663, 681 n.3 (1966) (Harlan \&: Stewart, JJ., dissenting). 
like race to meet the test of this refurbished precedent-conscious theory is unclear-and for good reason: This theory asserts that nationality and alienage are like race but is conspicuously silent as to just how. Thus, rather than advance the inquiry, this similarity criterion obfuscates the issues and implicitly restates the original question of what criteria define a suspect classification. ${ }^{26}$

Other theories, though, which have eschewed such logical circularity and have attempted to pinpoint precisely what about racial classifications summons strict scrutiny, provide a firmer basis for characterizing classification by mental illness as suspect or not. One view, for example, regards as controlling the opprobrium which racial classifications cast upon blacks. ${ }^{27}$ Classification on the basis of mental illness would seem to burden the mentally ill with similar stigma or opprobrium, for these laws, in which mental illness is a shorthand for various undesirable attributes, affirm to the mentally ill that others view them as inferiors. ${ }^{28}$ The opprobrium theory, however, is not without serious problems: Basically, although stigma is admittedly an explicit concern in many racial classification cases, this theory may be mistaking one type of harm commonly caused by suspect classifications with a requisite common denominator. The attention devoted to establishing opprobrium in various race cases, therefore, may be explained by the need to show some actual disadvantage resulting from the classification-the sine qua non of any equal protection claim. ${ }^{29}$

Another theory fixes on the unchangeableness of race as the source of suspicion about racial classifications. ${ }^{30}$ How this criterion would

26. And, again, as McLaughlin infers, the Court has been distinctively unhelpful in clarifying such matters. The following from Bolling v. Sharpe typifies the Court's elucidation of its reasoning on the essence of suspect classifications:

Classifications based solely upon race must be scrutinized with particular care,

since they are contrary to our traditions and hence constitutionally suspect.

347 U.S. 497, 499 (1954).

27. See, e.g., Black, The Lawfulness of the Segregation Decisions, 69 YALE L.J. 421, 426.27 (1960).

28. See M. Schwartz \& C. Schwartz, Soclal Approacies to Mental Patient Care 9 (1964) [hereinafter cited as Schwartz \& SchwarTz].

29. Thus, in cases subsequent to Brown v. Board of Educ., 347 U.S. 483 (1954), where the Court emphasized that the stigma of racial classification retarded blacks educational development, federal courts invalidated laws sanctioning separate but equal facilities where stigma did not seem to impair the black facilities' functional equivalence. See, e.g., New Orleans City Park Improvement Ass'n v. Detiege, 252 F.2d 122, 123 (5th Cir.), aff'd, 358 U.S. 54 (1958); Mayor \& City Council v. Dawson, 220 F.2d 386, 387 (4th Cir.), aff'd, 350 U.S. 877 (1955).

30. The origins of this theory may lie in Justice Jackson's eloquent dissent in Korematsu v. United States, 323 U.S. 214, 243 (1944):

But here is an attempt to make an otherwise innocent act a crime merely because this prisoner is the son of parents as to whom he had no choice, and belongs to a race from which there is no way to resign. 
apply to classification by mental illness is rather in doubt. Basically, the permanence of mental illness is a matter about which reasonable men may, and indeed do, differ. One prominent psychiatrist dichotomizes the diversity of opinion on this matter:

The old point of view assumed that most mental illness was progressive and refractory. The new point of view is that most mental illness serves its purpose and disappears, and does so more rapidly and completely when skillfully understood and dealt with. ${ }^{31}$

There are, however, those who, though not of the "old" point of view, regard mental illness as permanent because they see it as a tendency to gravitate toward the end of the continuum of mental health opposite to that portion which is arbitrarily labeled "normal."32 In addition, some, though not of the "new" point of view, consider mental illness to be impermanent because they feel that it is a state that can in some sense be willfully entered into and abandoned.33 A court adhering to a permanent characteristic theory could thus decide whether mental illness is a suspect classification only with great difficulty. ${ }^{34}$ The question, though, may simply be academic: Unless the Court is ready to overrule Graham v. Richardson $^{35}$ and later cases $^{36}$ holding alienage to be a suspect classification, it cannot logically subscribe to a permanent characteristic criterion. On the other hand, perhaps this theory can be read more broadly to have as its touchstone not an unchangeable characteristic but in-

Cf. Frontiero v. Richardson, 411 U.S. 677, 686 (1973) (plurality opinion); San Antonio Independent School Dist. v. Rodriguez, 411 U.S. 1, 109 (1973) (Marshall, J., dissenting): Weber v. Aetna Cas. \& Sur. Co., 406 U.S. 164, 175 (1972). See generally Note, The Legality of Homosexual Marriage, 82 YaLE L.J. 573, 576 \& n.11 (1973).

31. K. Menninger, The Vrtal Balance 2 (1963).

32. See S. Freud, A General Introduction to Psychonnalysis (1924). See also SchWARTZ \& SchWARTZ, supra note 28 , at 12-13.

33. See, e.g., R. Laing, The Politics of Experiexce (1967). In recounting the "psychotic episode," id. at 146, of one Jesse Watkins, Dr. Laing writes:

But he trusted his experience of having entered into a state of more, not less, reality, of hypersanity, not subsanity. To others, these two possibilities may bc no more distinguishable from each other than chalk from cheese. He had to bc careful. - . . Jesse felt that this experience was a stage that everyone would have to go through one way or another in order to reach a higher stage of evolution. . . Eventually he felt he couldn't "take" any more. He decided to come back.

Id. at 157-59 (emphasis in original).

34. Under this theory, the fact that a legislature regards mental illness as impermanent when it employs a mental illness classification does not mean that the court must decide that the classification is not suspect. The court's focus is not legislative intent but rather the ability of the members of the class to withdraw from that class.

35. 403 U.S. 365 (1971).

36. In re Griffiths, 413 U.S. 717 (1973); Sugarman v. Dougall, 413 U.S. 634 (1973). 
stead something closer to one very difficult to change. If so, mental illness, even if regarded as impermanent, may be "permanent enough" for this theory.

Analysis of these two leading theories of suspect classification thus reveals at least some support for the proposition that classification by mental illness is "like" classification by race and, accordingly, should be subject to strict scrutiny. Neither of these theories nor the central purpose formulation, however, provides a very satisfactory explanation of what the Court means when it calls a classification suspect. In the following pages this Note will develop a theory articulating what has moved the Court historically to declare classifications suspect and which should therefore guide it in future cases examining other classifications such as mental illness.

\section{A Theory for Suspect Classifications}

\section{A. The We-They Foundation ${ }^{37}$}

A clue to what the Court means when it calls a classification suspect may lie in what the Court does when it so labels it. Most obviously, the Court announces its intention to give the classification "strict scrutiny." Less obvious, however, is what the Court has thereby committed itself to do next. The Court's language in some of the suspect classification cases strongly suggests that the Court's exercise of strict scrutiny is equivalent to a demand that the classification chosen be precisely suited to serve a permissible state objective ss $^{3}$ that is, the classification must be neither over- nor underinclusive. Thus the majority in Loving $v$. Virginia asserted:

37. This subsection is based in large part on the "we-they" theory briefly outlined by Professor John Hart Ely in a footnote to The Wages of Crying Wolf: $A$ Comment on Roe v. Wade, 82 YALE L.J. 920, $933 \mathrm{n} .85$ (1973) [hereinafter cited as Ely, The Wages of Crying Wolf], and expounded at length by him in an unpublished paper. J.H. Ely, Judicial Review of Stspicious Classifications: Why is Classification by Race "Suspect," and Should Classification by Sex Similarly be Subjected to Extraordinary Scrutiny?, Spring 1971 (on file with the Yale Law Journal) [hereinafter cited as Ely]. All references to the latter are made with the permission of the author, whose generosity is acknowledged with great appreciation by the writer of this Note. All substantial departures from Professor Ely's theory are indicated in the footnotes. Differences in emphasis or in cases relied upon to support the same propositions are generally not noted.

38. This correlation, which does not appear to have been made by previous commentators, was very explicitly drawn by Professor Ely in his 1971 essay. Ely C6-14. For support he relies on Lee v. Washington, 390 U.S. 333 (1968); Tancil v. Woolls, 379 U.S. 19 (1964); Brown v. Board of Educ., 347 U.S. 483 (1954); Korematsu v. United States, 323 U.S. 214 (1944); Hirabayashi v. United States, 320 U.S. 81 (1943). 
At the very least, the Equal Protection Clause demands that racial classifications, especially suspect in criminal statutes, be subjected to the "most rigid scrutiny" . . and, if they are ever to be upheld, they must be shown to be necessary to the accomplishment of some permissible state objective. ${ }^{39}$

In this statement the Court appears to be demanding a perfect, or near perfect, classification. This standard is arguably dictum, however, since the case may be read as one in which the statute under review, one prohibiting miscegenation, was designed to achieve an impermissible state objective-specifically, "to maintain White Supremacy." 40

Korematsu ${ }^{41}$ and Hirabayashi, ${ }^{42}$ the Japanese internment cases, also suggest that the Court's focus in suspect classification cases is the relative perfection of the classification. In language not easily dismissed as dictum, they strongly imply that the applicable test is not perfection in classification but rather the most precise classification possible under the circumstances. Most probative perhaps in this respect is the following rationale offered by the Korematsu Court for upholding suspect classifications in both cases:

Like curfew, exclusion of those of Japanese origin was [in Hirabayashi] deemed necessary because of the presence of an unascertainable number of disloyal members of the group, most of whom we have no doubt were loyal to this country. It was because we could not reject the finding of the military authorities that it was impossible to bring about an immediate segregation of the disloyal from the loyal that we sustained the validity of the curfew order as applying to the whole group. In the instant case, temporary exclusion of the entire group was rested by the military on the same ground.43

39. 388 U.S. 1,11 (1967).

40. Id. at Il. A permissible state objective is not necessarily a compelling state objective. Unless the Court can pierce the veil of alleged legislative purposes and find only an unlawful objective, the statute in issue will survive a permissible state intercst test. Though not clearly decided on equal protection grounds, Anderson v. Martin, 375 U.S. 339, 404 (1964), seems to exemplify a finding of impermissible state interest:

we view the alleged equality [the requirement that the race of all contestants for public office appear on the ballot] as superficial. Race is the factor upon which the statute operates and its involvement promotes the ultimate discrimination which is sufficient to make it invalid.

On the other hand, a compelling state interest is not simply lawful but significant enough, in the Court's judgment, to outweigh whatever other interest appears to be jeopardized by its promotion. The inapplicability of a compelling state interest test to suspect classifications is discussed at pp. $1251-52$ infra.

41. 323 U.S. 214 (1944).

42. 320 U.S. 81 (1943).

43. 323 U.S. at 219 (emphasis added). 
Here the Court makes explicit its concern about imperfection of the classification: that segregation of some but not all Japanese nationals would serve the interests of national security, since some but not all are disloyal. ${ }^{44}$ Nevertheless, in this time of national emergency, the Court was willing to tolerate an imperfect classification as the best that the commanding general could manage in his presidentiallyauthorized order under the circumstances. ${ }^{45}$ In the Court's view, then, the need to take immediate measures to protect internal security excused the employment of Japanese nationality as a shorthand for the evils at which the order was aimed.

Finally, a brief concurring opinion in Lee $v$. Washington, ${ }^{46}$ a per curiam decision, also appears to equate strict scrutiny with a rule allowing deviation from perfection in classification only when circumstances dictate that some serviceable classification be formulated at once. ${ }^{47}$ In that concurrence three of the justices reiterated their agreement with the Lee Court's prohibition against racial segregation in prisons but hastened to add that the Court's opinion did not prevent prison officials from segregating prisoners along racial lines as a temporary relief measure to handle outbreaks of racial hostility. ${ }^{48}$

44. The Court does not expressly acknowledge the patent underinclusiveness of the internment measure: its failure to reach disloyal persons not of Japanese ancestry. Compare the following from Hirabayashi:

Because racial discriminations are in most circumstances irrelevant and therefore prohibited, it by no means follows that, in dealing with the perils of war, Congress and the Executive are wholly precluded from taking into account those facts and circumstances which are relevant to measures for our national defense and for the successful prosecution of the war, and which may in fact place citizens of one ancestry in a different category from others.

320 U.S. at 100 .

45. The executive order, "issued after we were at war with Japan, declared that 'the successful prosecution of the war requires every possible protection against espionage and against sabotage...." 323 U.S. at 217. The Court readily acknowledged that it was "not unmindful of the hardships imposed by [the commanding general's exclusion order] upon a large body of American citizens," id. at 219, and that "[n]othing short of apprehension by the proper military authorities of the gravest imminent danger to the public safety can constitutionally justify [such an order]." Id. at 218 (emphasis added). "But when under conditions of modern warfare our shores are threatened by hostile forces," said Justice Black for the Court, "the power to protect must be commensurate with the threatened danger." Id. at 220 .

46. 390 U.S. 333, 334 (1968) (Black, Harlan \& Stewart, JJ., concurring).

47. Although Professor Ely does not explicitly make immediacy the applicable test for judging the validity of deviations from perfection, this does appear to be the thrust of his statements regarding the best possible classification "under the circumstances," Ely, supra note 37, at CI1, or "as the circumstances will allow." Id. at C12. Insofar as this may not be the case, the writer of this Note assumes sole responsibility for the formulation and its implications.

48. The concurring Justices insisted that, under the Court's affirmance, prison authorities retained "the right, acting in good faith and in particularized circumstances, to take into account racial tensions in maintaining security, discipline, and good order in prisons and jails." 390 U.S. at 334. The state had contended that the district court's order made "no allowance for the necessities of prison security and discipline," but the Court, in its per curiam opinion, did "not so read the "Order, Judgment and 
Although separating some black prisoners from some white prisoners would almost certainly be unnecessary to further the goal of preventing violence (since neither all blacks nor all whites would be expected to demonstrate outward racial hostility), the classification may be justified in an emergency as the best possible given the time available for its formulation. 49

This interpretation of "strict scrutiny," furthermore, helps explain those suspect classification cases in which the law at issue was declared invalid. Consider, for example, the landmark suspect classification case, Brown $v$. Board of Education..$^{\overline{0}}$ An arguably permissible state objective for the laws at issue in Brown, laws requiring or permitting segregation in public schools according to race, would be to accelerate the education of youths according to their intellectual abilities. The classification in Brown ostensibly attempted to serve this goal by equating whites with those students most able to accelerate and blacks with those least able. ${ }^{51}$ Although these equations may have been true as general descriptive propositions, the classification was obviously imperfect, in that it was both over- and underinclusive. Accordingly, the Court struck down the laws and thereby forced the state to classify along nonracial lines (e.g., by aptitude tests $\left.^{52}\right)$ in pursuing lawful educational objectives. ${ }^{53}$

Decree' of the district Court . . . Id. The concurring Justices sought "to make explicit something that is left to be gathered only by implication from the Court's opinion." Id.

49. Professor Ely argues that Tancil v. Woolls, 379 U.S. 19 (1964), another per curiam opinion, may also be read as authority for a test requiring the best classification possible under the circumstances. Ely, supra note 37, at Ci2-13. The law at issue required that all divorce decrees denote the race of each spouse, apparently for purposes of generating comprehensive vital statistics. Professor Ely argues that the perfection of this classification explains the Court's willingness to uphold this law, and the court below indeed appeared to proceed on such a theory, Hamm v. Virginia State Bd. of Elections, 230 F. Supp. 156, 158 (E.D. Va. 1964). The Court's failure to elucidate the basis for its affirmance, however, leaves open the possibility that the Court proceeded on another theory: that the law under review harmed no one (by stigma or otherwise) and thus raised no equal protection issue at all.

50. 347 U.S. 483 (1954).

51. Cf. Brief for Att'y Gen. of Fla. as Amicus Curiae at 19-20, Brown v. Board of Educ., 349 U.S. 294 (1955).

52. Whether an aptitude test exists that will give a fair, racially-neutral reflection of intellectual abilities is of course debatable. On aptitude tests and pupil assignment, see Jones v. School Bd., 278 F.2d 72, 77 (4th Cir. 1960); Borders v. Rippy, 247 F.2d 268, 271 (9th Cir. 1957). But cf. Still v. Board of Educ., 387 F.2d 486, 491 (5th Cir. 1967).

53. Although Brown has taken on the status of the suspect classification case, the Court's opinion in Brown makes no mention of "suspect classification" and appears to rely exclusively on a fundamental right to an equal education. It is the companion case to Brown, Bolling v. Sharpe, 347 U.S. 497,499 (1954), that enunciates the suspect status of classification by race. Since San Antonio Independent School Dist. v. Rodriguez, 411 U.S. 1 (1973), holds that education is not a fundamental interest, Brown can sensibly be viewed only as a suspect classification case. Thus, Rodriguez appears to have made Brown's landmark status secure even among those who may take the language in Brown literally. 
Subsequent per curiam opinions resting on the authority of Brown also vindicate this interpretation of "strict scrutiny." Basically, these decisions declaring segregated public facilities-beaches, ${ }^{54}$ buses, ${ }^{55}$ courtrooms, ${ }^{56}$ and golf courses ${ }^{57}$ to be in violation of the Fourteenth Amendment implicitly state the general rule from which the Lee concurrence carves an exception. Thus, as in the Lee racial violence hypothetical, the permissible state goal is the preservation of order..$^{58}$ A classification by race could serve this goal by minimizing contact among two groups in society likely to be antagonistic to one another -the white and black races. Again, the basic proposition may be plausible: Given the generally prevailing social and cultural differences between the races, friction between a white and a black is arguably more probable than between two whites or two blacks. In the Lee hypothetical the imminent threat of violence would excuse a racial classification as the best that could be managed by prison authorities in the brief time available to them. On the other hand, unless there is a discernible cause for immediate imposition of a racial classification on a beach or golf course, the patently imperfect racial classification of segregated facilities would be impermissible. Authorities would be denied the convenient racial shorthand and remitted to case-by-case determinations of which individuals are likely to be disruptive. Some may object that the latter course will be prohibitively expensive. And so it may. But cost is not a consideration relevant to the constitutionality of a suspect classification.

A final illustration of the general validity of this analytic method is Graham v. Richardson, ${ }^{59}$ the occasion for the Court's announcement that classification by alienage is suspect. The laws challenged in Graham deprived aliens of welfare benefits awarded to equally needy United States citizens residing in the state. Two permissible state goals appear to inform the classification: maintaining welfare expenditures at a level compatible with other demands on the state's purse and giving preferential treatment to those state residents likely to have contributed more, monetarily or otherwise, to the commonweal. ${ }^{00}$ The state's classification scheme was not irrational. But strict

54. Mayor \& City Council v. Dawson, 350 U.S. 877 (1955).

55. Gayle v. Browder, 352 U.S. 903 (1956).

56. Johnson v. Virginia, 373 U.S. 61 (1963).

57. Holmes v. City of Atlanta, 350 U.S. 879 (1955). See Burton v. Wilmington Parking Auth., 365 U.S. 715 (1961) (restaurant in public building); New Orleans City Park Improvement Ass'n v. Detiege, 358 U.S. 54 (1958) (parks).

58. See Petitioners' Brief for Certiorari at 17, Mayor \& City Council v. Dawson, 350 U.S. 877 (1955).

59. 403 U.S. 365 (1971).

60. Cf. id. at $372-76$. 
scrutiny demands perfection in classification unless considerations of immediacy obtain. The Court was thus obliged to declare the welfare laws under review in Graham to be unconstitutional. Perhaps other devices for giving priority to the most deserving residents, devices avoiding the defect of over- and underinclusiveness, may be too expensive to implement. Again, however, imperfection in a suspect classification is not excused by cost considerations.

If strict scrutiny demands perfection in classification absent conditions requiring immediate reaction, a possible explanation of what the Court finds so suspicious about suspect classifications emerges. Basically, the Court may be sensitive to classifications by race, alienage, or nationality because it distrusts the process by which such classifications are generated. This suspicion of the legislative process may derive from legislators' unfitness to weigh the costs and benefits of greater individualization in classification when they classify along these suspect lines. For in such instances they may have personal stakes which skew their perceptions of the cost-benefit balance.

A closer look at the classification process brings this problem of bias into relief. A legislative classification rests upon a stereotypical comparison of two classes of persons. For example, legislators may believe that persons in class $A$ (doctors) are generally better qualified than those in class $B$ (chiropractors) in several respects, thus justifying the classification made (doctors may prescribe medicines and chiropractors may not). Since presumably few legislators are doctors or chiropractors, there is-at least in the absence of external evidence to the contrary-little reason to suppose that this comparison is tainted with self-interest. Focusing, then, on those vested with formal authority to make the above classification and on those affected by the classification, one is led to presume that the legislation is basically objective and fair. If members from either of the two classes being compared constitute a majority of the legislature, however, the comparative generalizations and cost-benefit balances made are inherently untrustworthy for a number of reasons. First, in comparing us (whites) to them (blacks), members of the predominantly white legislature may, because of the not uncommon human desire to affirm one's own superiority, tend to assume the good about us and the bad about them. Similarly, because of an equally innate selfcenteredness, the legislators may be inclined to believe that the proposed classification neither serves us too well nor them too poorly. Accordingly, consciously or unconsciously, we, the legislators, skew the balance in our favor by underestimating the benefit (the in- 
crease in fairness) to them from a more precise classification. The presumption of legislative objectivity which would inform judicial deference to a legislative they-they (doctor-chiropractor) balance is out of place where a we-they balance is involved for yet another reason: We are most likely to overestimate the costs of greater individualization when a more neatly-fitted classification would bring more of them into equality with us. In essence, since the psychological forces at work cast doubt upon the objective fairness of we-they generalizations and balances, the courts ${ }^{61}$ properly give special scrutiny to classifications made on the basis of such potentially biased generalizations and balances. ${ }^{62}$

Classifications based on race, ancestry, and alienage, the three classifications explicitly given suspect status by the Court, arise in classic we-they situations. Anytime we (a predominantly white, Americanborn and descended legislature) ${ }^{03}$ compare ourselves to them (blacks, aliens, and other persons of foreign ancestry), the court should closely scrutinize the classification. If not perfect, the classification must be justified in its imperfection by exigent circumstances.

It should be emphasized at this point that the goal served by the classification need be only permissible, not compelling. Thus, if the classification is perfect or justifiably imperfect, the reviewing court should not proceed to inquire into how compelling the asserted state interest is. Although some might think such substantive testing desirable, the Court does not appear in its holdings to have committed itself to test for a compelling state interest. ${ }^{6 t}$ Indeed, if, as maintained, the Court's concern in suspect classification cases is with purity of process rather than with a specific substantive interest (as is the case when a deprivation of First Amendment" or other "fundamental" rights is the issue), it seems inappropriate for the Court to test for a compelling state interest.

61. The point is not that we-they generalizations made by courts are more trustworthy than those made by Iegislatures. Given their typical instulation from popular accountability, courts may well be less competent to perform such a task. But they can nevertheless decide when no one, including themselves, should be allowed to generalize. Thus, the issue before the Court in suspect classification cases is not who should generalize and balance but whether anyone should. See Ely, The Wages of Crying Wolf, supra note 37 , at 933 n.85. On bias in adjudicatory contexts, see, e.g., Gibson v. Berryhill, 411 U.S. 564 (1973); Ward v. Village of Monroeville, 409 U.S. 57 (1972).

62. This paragraph essentially tracks Professor Ely's theory. Ely, The Wages of Crying Wolf, supra note 37 , at 933 n.85.

63. If the numerical imbalance in a legislature were redressed, classifications which were once we-thcy and suspect would lose that status. But cf. id.

64. See Ely, supra note 37, at $\mathrm{Cl} 4$.

65. See, e.g., United States v. Robel, 389 U.S. 258 (1967); Cox v. Louisiana, 379 U.S. 536 (1965). 
If many, including members of the present Court, share a contrary view, ${ }^{68}$ the confusion appears to derive from three sources. ${ }^{67}$ First, deprivation of a fundamental interest does trigger a compelling state interest test. In some fundamental interest decisions long assumed by many scholars and courts to rest on suspect classification grounds as well (or, perhaps, on these latter grounds alone), ${ }^{68}$ the Court's discussion of compelling state interests may have confused the issue. Also tending to obscure the issue is the fact that some suspect classification cases were decided on the basis of a finding of no lawful state interest. ${ }^{69}$ In this group of cases the Court may even allude to an "overriding" state interest doctrine,70 but the cases rest in fact on the application of the far less rigorous and interventionist permissible state interest test. Finally, the emphasis on emergency circumstances in the Japanese internment cases and in the Lee v. Washington concurrence might easily be read as a discussion of the compelling state interest doctrine. The Court discussed these exigencies, however, only to justify its allowance of an imperfect classification which was the best that authorities could manage within the short time available for the classification's formulation; the Court's discussion was not an independent evaluation of the extent to which the state interest involved was compelling. The distinction is a crucial one: Even where the classification is perfect, the compelling state interest doctrine would require the reviewing court to assess the state's objective and invalidate the law if it found the interest not sufficiently compelling; on the other hand, if the test requires only the most precise classification possible within given temporal limitations, perfection in classification ends the matter.

66. See p. 1268 infra. In Eisenstadt v. Baird, 405 U.S. 438,447 n.7 (1972) (dictum), the Court cited Loving v. Virginia, 388 U.S. I (1967), a suspect classification case, as authority for requiring a showing of a compelling state interest.

67. This elucidation of sources is not part of Professor Ely's thesis.

68. See, e.g., Shapiro v. Thompson, 394 U.S. 618 (1969); Harper v. Virginia Bd. of Elections, 383 U.S. 663 (1966); Douglas v. California, 372 U.S. 353 (1963); Griffin v. Illinois, 351 U.S. 12 (1956). For commentary expressly or implicitly reading these cases as authority for wealth as a suspect classification, see G. GUNTHER \& N. DowLING, Constitutional Law 1011-12, 1018-19 (8th ed. 1970); Willcox \& Bloustein, The Griffin Case-Poverty and the Fourteenth Amendment, 43 CoRNell L.Q. 1, 9-10 (1957); Note, Discriminations Against the Poor and the Fourteenth Amendment, 81 Harv. L. Rev. 435, 437-38 (1967); Note, New Vistas in Protecting the Indigent: Rewriting Griffin and Douglas, 4 SUFF. U.L. Rev. 485, 499 (1970); 28 Öно Sr. L.J. 189, 193 (1967).

69. See discussion of Loving v. Virginia, 388 U.S. 1 (196\%), and Anderson v. Martin, 375 U.S. 399 (1964), in note 40 supra and the accompanying text.

70. Loving v. Virginia, 388 U.S. 1, 11 (1967):

There is patently no legitimate overriding purpose independent of invidious racial discrimination which justifies this classification... [T] he racial measures must stand on their own justification, as measures designed to maintain White Supremacy. 


\section{B. Political Realities and the Legislative Process}

\section{The Limits of the We-They Analysis}

Since this we-they theory attempts to articulate what has moved the Court to declare some classifications suspect, the theory would fail on its own terms unless it affirmed the suspect status of the few classifications bearing the Court's imprimatur of suspicion. On the other hand, this theory must exclude from possible suspect status those classifications that the Court would almost intuitively regard as beyond suspicion-or at least unsuspicious enough that society's resources would best be allocated by allowing legislatures to employ such classifications.

A few examples should illustrate the problem:

Case One. The legislature of State $X$ is composed principally of psychiatrists. It passes a law prohibiting psychologists from administering shock therapy. Psychologists from that state bring a class action claiming a denial of equal protection and seeking invalidation of the law.

If the we-they theory alone explains suspect classifications, the psychologists should win the case. The comparative we-they generalization explaining the classification must be: We (psychiatrists) are more qualified than they (psychologists) in terms of the education and abilities needed to administer shock treatment safely and wisely. Now most psychiatrists are probably more competent to administer shock treatments than most psychologists, but some psychologists are undoubtedly more competent than some psychiatrists to perform this task. Thus, although the classification is rational, it is far from perfect. It seems unlikely, however, that the courts would invalidate this under- and overinclusive law and thereby burden the system with the case-by-case determinations required to assure more precise service of the goal.

Case Two. Lawyers predominate in the legislature of State $Y$. The legislature enacts an attorney-client privilege but fails to pass a bill establishing an accountant-client privilege. The state's accountants bring a class action claiming a denial of equal protection and asking the court to extend an analogous privilege to them.

Again, a court adhering to the we-they theory alone as the touchstone for suspect classifications should grant relief to the plaintiffs. 
Assuming (for purposes of this illustration) that the legislative purpose is to protect business health, ${ }^{71}$ the comparative generalization explaining the classification is: We (lawyers) need this privilege to protect our businesses more than they (accountants) need one to protect theirs. ${ }^{22}$ But even if most lawyers need this privilege more than most accountants to retain their clientele, surely some accountants need it more than some lawyers. Given this imperfection in classification and the absence of any apparent justification for it, the suspect classification could not stand. It somehow seems dubious, though, that a court would demand anything approaching perfection in this classification or, indeed, that it would even find this law at all suspicious.

\section{A Needed Refinement of the Theory}

Although the we-they relationship of legislators and persons being classified is a necessary characteristic of suspect classification, the above illustrations intimate the presence of at least one other necessary characteristic. The missing criterion must remedy the we-they theory's obvious overinclusiveness. This criterion may be that the they-group be politically impotent, a prototype of the "discrete and insular minorities" of which Mr. Justice Stone speaks in his famous Carolene Products footnote. ${ }^{73}$ The examples above illustrate the need to modify the theory of suspect classifications to take account of political realities-specifically, the presence of powerful lobbies representing groups with little or no actual representation in the legis-

71. Though almost certainly secondary to other legislative goals (e.g., buttressing the adversary process by encouraging clients to confide in counsel), this goal is at least arguably present. See In re Lifschutz, 2 Cal. 3d 415, 427-29, 467 P.2d 557, 564-66, 82 Cal. Rptr. 647, 654-56 (1970) (defendant's contention).

72. Professor Ely focuses exclusively on the suspect nature of we-they generalizations as to comparative qualifications. Equally suspect under his theory would be we-they generalizations as to comparative need. Suppose Congress passes a, law establishing a salary ratio of $3: 2$ at all civil service grades for men and women, respectively. The basis for this distinction is the we-they generalization that men are generally in greater need of money than women since families rely on the man for support. This selfserving generalization ought to be regarded as suspect. Plessy v. Ferguson, 163 U.S. 537 (1896), is despicable in large part because it callously affirms a gross misrepresentation of comparative need: We [whites] need public facilities to be segregated more than they [blacks] need them not to be. Thus eight members of the all-white Court showed great solicitude for the comfort and happiness of whites and brushed aside the competing claim of blacks for human dignity:

We consider the underlying fallacy of the plaintiff's argument to consist in the assumption that the enforced separation of the two races stamps the colored race with a badge of inferiority. If this be so, it is not by reason of anything found in the act, but solely because the colored race chooses to put that construction upon it.

Id. at 551. But see id. at 562 (Harlan, J., dissenting).

73. United States v. Carolene Prods. Co., 304 U.S. 144, 153 n.4 (1938). 
lature. ${ }^{7 t}$ Thus, if intuition would suggest that the psychologists in Case One and the accountants in Case Two would meet with little success in court, perhaps the explanation lies in a tacit recognition of their participation in the legislative process through indirect channels.

Adding the intangible element of political power to the theory does destroy the neatness of nose-counting (all that is apparently required by we-they). On the other hand, it does not, with its emphasis on polar cases, seem to call upon the courts to make findings on, or take judicial notice of, legislative facts ${ }^{75}$ more difficult to ascertain than usual. ${ }^{76}$ Although a court should strive for an overview of all relevant characteristics in assessing a they-group's "outsider" status, four criteria would seem to be particularly relevant to this determination. The first is whether the group has the right to vote. An answer either way should not in itself determine the court's ultimate finding as to political impotence and suspect classification. If the class cannot vote, Oregon $v$. Mitchell ${ }^{77}$ cautions against con-

74. Unparalleled for the insight which it offers on such matters is H. LASSwELI, PouttICs: Who GETS WHAT, WHEN, How (1958), especially at 13-27. A recent illustration of this approach to public decisions and a brief summary of its various aspects may be found in Reisman \& Simson, Interstate Agreements in the American Federal System, 27 RutGers L. Rev. 70, 70-74, 81-82 (1973).

75. On findings and official notice of legislative as compared to adjudicative facts by the courts, see $2 \mathrm{~K}$. Davis, Administrative Law Treatise $\$ 15.03$ (1958), and cases cited therein. In general,

When a court or an agency finds facts concerning the immediate parties-who did what, where, when, how, and with what motive or intent-the court or agency is performing an adjudicative function and the facts are conveniently called adjudicative facts. When a court or an agency develops law or policy, it is acting legislatively; the courts have created the common law through judicial legislation, and the facts which inform the tribunal's legislative judgment are called legislative facts.

Id. at 353 .

76. See, e.g., Leary v. United States, 395 U.S. 6, $39-43$ (1969); Brown v. Board of Educ., 347 U.S. 483, 494 n.11 (1954).

77. 400 U.S. 112 (1970). In Mitchell the Court held that Congress had no authority under $\$$ five of the Fourteenth Amendment to lower the voting age in state elections to 18. Though lacking the right to vote, 18 to 21 year olds did not, said the Court, need protection (at least not in the form of an extension of the right to vote to them) against discrimination. One implication of this holding would seem to be that youth is not a suspect classification, from which it would follow that inability to vote does not in itself qualify the they-group for suspect status.

The Court may not, though, have definitively voted youth "out" as a suspect clas. sification. Three of the five Justices concurring in striking down the state elections provision in Mitchell pointed to $\S$ two of the Fourteenth Amendment for support:

Moreover, so long as a State does not set the voting age higher than 21, the reasonableness of its choice is confirmed by the very Fourteenth Amendment upon which the Government relies. Section 2 of that Amendment provides for sanctions when the right to vote "is denied to any of the male inhabitants of such State, being twenty-one years of age, and citizens of the United States . . ."

Id. at 295. To similar effect, see N.Y. Times, Apr. 5, 1970, $\S 4$, at 13, col. 1 (letter of Professors Bickel, Black, Bork, Ely, Pollak, and Rostow). Although the Court has never explicitly held that $\S$ two affirms the reasonableness of 21 as a voting age, its treatment of 
cluding automatically that it is an outsider group and thus that wethey classifications involving it are suspect. On the other hand, a class that can vote may still be an outsider group and we-they classifications involving it may still be suspect: Blacks can vote, but they may still be effectively excluded from the political process. Though neither sufficient nor necessary to support a finding of outsider status, a group's inability to vote at least suggests that its input in the political process will be relatively meager.

The second consideration is whether the group is a minority in the general population. Again, a "yes" or "no" answer is not dispositive for purposes of the determination of political impotence: Many minority groups-e.g., doctors and lawyers-are quite potent politically; on the other hand, Mr. Justice Stone's "discrete and insular minorities" notwithstanding, a they-group merits the protection of the scrutiny given suspect classifications whether it is in the majority ${ }^{78}$ or minority as long as it is politically powerless. A group's minority status is relevant, though, in that it may suggest an inability, even with the vote, to protect the group's interests in the political arena.

The third consideration is how insular the group is. If a class does not interact with other groups in society, one might infer that it would lack any surrogate voices (if it cannot vote) or complementary voices (if it can) in its behalf in the political process. Nevertheless, insularity would not seem a sufficient characteristic of outsider

the other classifications ostensibly legitimated for voting purposes by the express language of $\S$ two (i.e., sex, state residency, United States citizenship, and commission of a felony) supports such an inference. Basically, since the right to vote has been held to be a "fundamental interest," Harper v. Virginia Bd. of Elections, 383 U.S. 663 (1966), one might anticipate that any classification for voting purposes would be subjected to strict scrutiny and, hence, tested for a compelling state interest. But the Court regularly defers to classification by residency and citizenship, see, e.g., Kramer v. Union Free School Dist., 395 U.S. 621, 625 (1969), and has recently summarily affirmed an exclusion of felons from the franchise, Fincher v. Scott, 411 U.S. 961 (1973), aff'g 352 F. Supp. 117 (M.D.N.C. 1972). In Fincher, furthermore, the lower court explicitly rested the validity of the classification on $\$$ two of the Fourteenth Amendment. $352 \mathrm{~F}$. Supp. at 119. See also Green v. Board of Elections, 380 F.2d 445, 452 (2d Cir. 1967). (Classification by sex for voting purposes lacks any similar authority because the Nineteenth Amendment presumably supersedes $\$$ two's delegation of authority to discriminate among voters on the basis of sex.)

If age discrimination for voting purposes derives its constitutionality from $\$$ two of the Fourteenth Amendment, therefore, perhaps Mitchell may be read as simply a "voting case," i.e., an illustration of the special status carved out by $\$$ two for discriminations among potential voters, and not a statement by the Court on the unsuspect nature of classification on the basis of youth. The implication of this reading of Mitchell in terms of the voting criterion for political impotence would be that inability to vote indicates an outsider group at least where it can also be shown that the they-group has no effective surrogates in the political arena. On surrogates, sec note 79 infra and accompanying text.

78. On one majority group, women, see notes 79,81 infra. 
groups-at least insofar as the they-group has chosen this insularity (e.g., "high" society)-nor a necessary one-at least where the noninsular they-group for other reasons lacks surrogate or complementary voices in the political process. ${ }^{79}$

The final consideration is whether the group has been repeatedly disadvantaged or stigmatized ${ }^{80}$ by legislative classifications. Generally, where a they-group has suffered harm with great frequency as the result of past and present imperfect classifications, one might well infer that it lacks effective input into the political process. This last consideration perhaps comes closest to a sufficient and necessary characteristic of outsider groups. ${ }^{81}$

This revised we-they theory would still embrace the three classifications declared suspect by the Court ${ }^{82}$ and, at the same time, exclude numerous classifications seemingly beyond suspicion. Theygroups like psychologists and accountants, therefore, plainly could not invoke the protection of this suspect classification theory: Any

79. Even though a they-group interacts with various other groups in society, a court might find that denial of the vote to members of the group is not remedied by the presence of ostensible sturrogates. The court may decide that an ostensible surrogate is not a surrogate at all because the supposed stand-in has interests frequently adverse to those of the members of the class for which it appears to speak. A court appropriately receptive to all relevant characteristics of the they-group, therefore, might find in denial of the vote to juveniles some evidence that the classification is suspect on the theory that parents have interests in sufficient conflict with the they-group's to make them poor stand-ins for the latter. The presence of a pattern of discriminatory legislation, the fourth criterion, see text accompanying note $80 \mathrm{infra}$, would be a strong indication to a court of such an inherent conflict of interests where surrogates seem to exist. The same considerations would obtain, though perhaps not as forcefully, where complementary voices are the issue. Thus, in gauging the political potency of women (pursuant to an inquiry into the suspect status of classification by sex), a court would want to consider that husbands, whose voting power would ostensibly complement women's, in fact have interests in sufficient conflict with women's. See, e.g., M. HAsKeLL, From Reverence to Raie 14 (1973); K. Millett, Sexual Politics 66-73 (1969). Accordingly, the political power of the they-group (women) would be largely limited to their own exercise of the franchise and not be supported with any degree of consistency by a complementary voice.

80. Although stigma is regarded as simply one type of disadvantage, see p. 1243 supra, both terms are used in the accompanying text to avoid any inference that laws singling out a they-group for "advantage"-e.g., a law providing that women cannot be drafted-may not be harmful and in fact indicative of discriminatory treatment. See note 92 infra.

81. Indeed, in Frontiero v. Richardson, 411 U.S. 677, 684-86 (1973), where four of the Justices concurred that sex is a suspect classification, the plurality opinion appeared to place primary reliance on this criterion. See also San Antonio Independent School Dist. v. Rodriguez, 411 U.S. 1, 28 (1973); Hobson v. Hansen, 269 F. Supp. 401, 507-08 (D D.C. 1967), remanded on other grounds sub nom. Smuck v. Hobson, 402 F.2d 175 (D.C. Cir. 1969).

82. Thus, as to race, the they-group (blacks) would satisfy the latter three criteria; as to alienage, the they-group (aliens) would meet all four (satisfaction of the fourth criterion is elucidated in Graham v. Richardson, 403 U.S. 365, 371-76 (1971), and witnessed in the "special public interest" doctrine, Truax v. Raich, 239 U.S. 33 (1915)); and as to nationality, the they-group (forcign nationals) will have some nonvoting members (aliens), be a minority, and be insular and suffer disadvantage in classification in varying degrees according to the identity of the particular nationality. Although this checklist of relevant considerations provides a useful reference, it should be recalled that the test is political impotence, not satisfaction of any set number of these criteria. 
inference of political impotence arising out of their minority status in the society at large would be soundly dispelled by their retention of the franchise, interaction with a multitude of other groups, and, by all indications, failure to experience repeated disadvantage in the classification process. But, again, these criteria are only illustrative, not exhaustive, of those which a court might wish to consider in its estimation of a group's political impotence. Mechanical application of the suggested criteria would run counter to the basic thrust of the test for political power, which must be attuned to the political realities of the world outside the courtroom. It is with attention to such realities, then, that the qualifications of the class of persons labelled mentally ill for admission to the suspect circle should be judged.

\section{Application of the Theory to Classification on the Basis of Mental Illness}

\section{A. The Suspect Nature of Classification by Mental Illness}

The sine qua non for mental illness to qualify as a suspect classification is numerical domination of legislatures by persons not mentally ill. Except perhaps in moments of acute pessimism about the human condition, ${ }^{83}$ any court could be expected to take judicial notice of the they-status of the mentally ill. ${ }^{84}$ Accordingly, legislative classification on the basis of mental illness is easily subject to the we-they analysis.

Moreover, suspicion seems especially appropriate when this particular we-group, "normal" persons, compares itself to this particular they-group, the mentally ill. The usual tendencies to assume the good about us and the bad about them and to be solicitous of our needs and callous to theirs become exaggerated. Like the other forces at work that cast suspicion on we-they generalizations, this exaggerating force partakes of psychology and the subconscious. ${ }^{85}$ We

83. For the proposition that we are all mentally ill, see ScHwarTz \& SchwarTz, supra note 28 , at 14 .

84. Although a large body of opinion holds that everyone is capable, given sufficient stress, of becoming mentally ill, id. at 13 , one should not conclude from this that legislators will therefore identify with the mentally ill and, hence, that the mentally ill do not comprise a they-group. On the strong contrary tendency of "normal" persons to disassociate themselves as much as possible from the mentally ill, see pp. 1258. 59 infra.

85. In Freudian terms, see S. Freud, The Ego and the ID $18-29$ (2d ed. 1960), it is the defensive reaction of our (normal persons') egos to the threat posed to our superegos by expressions of deviant behavior. These expressions awaken our own repressed impulses. When legislators enact laws that affirm our differences from them, the ego is giving authoritative support to the superego and thereby strengthening its own powers to keep deviant impulses in check; cf. F. Alexander \& H. STAUB, ThE Criminal, the Judge and the Public 214-15 (1956). 
all fear turning into them and thus are only too ready to assuage these fears by telling ourselves how unlike them we really are.80 Accordingly, we will generalize strongly in our favor in comparing us to them and will underestimate, even more than might otherwise be anticipated in we-they situations, the benefits to them of greater precision in classification. Similarly, in obeying our subconscious desire to distance us from them, we will overestimate, even more than usual, the costs of treating them as equals. ${ }^{87}$

Finally, as one of the foremost "discrete and insular minorities," the mentally ill warrant the special judicial solicitude reserved for other politically impotent they-groups: We-they classifications on the basis of mental illness should be treated as constitutionally suspect. The political impotence of the mentally ill is manifest in terms of the four criteria enumerated above for outsider status. In the various states the mentally ill will almost certainly meet three and often four of these criteria: They may be deprived of the right to vote; ${ }^{88}$ they are (notwithstanding the opinion of psychologists who would have us believe that everyone is mentally ill ${ }^{89}$ invariably in the minority; they are, as a result of "normal" persons' aversion to personal contact with them, regularly consigned to insularity; and they are typically victimized by ill-fitting legislative classifications. ${ }^{90}$

\section{B. The Impact of Strict Scrutiny on Laws Classifying on the Basis of Mental Illness}

If mental illness is indeed a suspect classification, then courts are bound to give strict scrutiny to any law employing this classification. To be upheld, therefore, the classification must be perfect or satisfy

86. See R. Donnelly, J. Goldstein \& R. Schwartz, Criminal Law 819 (1962), quoting S. Star, The Public's Ideas about Mental Illness, 1955 (unpublished paper presented to the 1955 Annual Meeting of the National Association for Mental Health).

87. In reviewing civil commitment laws (as contrasted, for example, with laws prohibiting mentally ill persons from practicing certain professions), a court may be right to assume that the legislative cost-benefit balance for mental illness classifications is particularly untrustworthy. Given the anxiety which the mentally ill produce in "us" about our own sanity, the possibility of removing the mentally ill from sight-the possibility offered by commitment laws-would seem to invite misjudgment. As one commentator has flatly suggested:

$A$ fourth function [of commitment] . . is one that legislatures would be embarrassed to express in statutory language and state courts unwilling to acknowledge: Commitment serves to remove from sight those who make us feel uncomfortable. An ill person may pose no physical threat to our person or property yet unsettle us when we encounter him. Even if silent and withdrawn, he may cause us to worry about our own stability and create anxieties about our own sanity.

Chambers, Alternatives to Civil Commitment, 70 MICH. L. REv. 1107, 1119-20 (1972).

88. See p. 1267 infra.

89. See note 83 supra.

90. See pp. 1260-68 infra. 
the narrow immediacy exception for imperfection. Although this standard does not call for substantive testing;, ${ }^{91}$ strict scrutiny of laws classifying on the basis of mental illness does, as the following discussion will hopefully demonstrate, produce dramatic results. ${ }^{92}$

\section{Laws Regulating the Givil Commitment Process}

\section{a. The Constitutional Attack on Commitment Standards}

Prominent among the laws brought under strict scrutiny would be those governing who can be civilly committed. Consider first the commonly found law authorizing the detention of any person mentally ill and dangerous to others. ${ }^{93}$ If the legislature's purpose

91. See pp. 1251-52 supra.

92. The method of judicial review set out in the text below differs significantly from that suggested by Professor Ely. He argues that only those specific laws rooted in a "suspicious" we-they comparative generalization-i.e., we are superior to or more qualified than they are in the following respects-should be regarded as suspect. Ely, supra note 37 , at C28-41. This unnecessarily confuses the issue and gives the courts an onerous, if not highly artificial, task to perform. That we-they generalizations and balances are by their nature suspicious is crucial to explain why we-they classifications are suspect. There is simply no need, however, to delve into legislative motive in each case in search of a suspicious-looking generalization. Having decided that a given classification is we-they and thus suspect, one can then assume that a law employing that classification merits strict scrutiny, i.e., that the generalizations made and balances struck are tainted by the personal interests of the we-group. If the classification is perfect or imperfect but excused by exigent circumstances, the classification will survive nonetheless.

In insisting upon focusing on the underlying generalization, Professor Ely is apparently concerned to avoid invalidating laws designed to promote integration or to compensate the they-group for discrimination practiced against them. Such laws are not, he asserts, rooted in suspicious comparative generalizations. But the laws to promote integration are no problem in any case. For as Professor Ely himself points out earlier in his essay, id. at C13-14, many of these laws embody a perfect classification: Every student bused, for example, serves the objective of integrating the schools. Such laws would therefore survive even strict scrutiny. Among the second group of statutesthose which compensate for societal prejudices-Professor Ely would include a law providing an extra tax exemption for blacks (since many blacks are "consigned by societal prejudices to jobs financially less rewarding than their qualifications would indicate they should be doing," id. at C29-30) and protective wage and hour legislation for women (since, "because of societal prejudice, women would be less capable than men of equal qualification of protecting themselves at the bargaining table," $i d$. at C38-39). It is not at all clear that one should want to rescue these laws. They seem no less stigmatizing, and thus harmful, to the they-group than others also designed to favor the they'group but less elegantly cloaked in neutral, inoffensive generablity-e.g., laws keeping women out of especially dangerous occupations (read: "they [women] are frailer than we [men] are"). In any event the Court may soon express its opinion on the matter when it decides the legality of a quota system which has the arguable effect of excluding some white applicants to law school who would otherwise have been admitted. DeFunis v. Odegaard, 82. Wash. 2d 11, 507 P.2d 1169, cert. granted, 94 S. Ct. 538 (1973).

The search for the suspicious generalization can thus be a highly subjective exercise. A more value-neutral test would subject every law based on a suspect classification, one of a we-they nature where the they-group is politically impotent, to strict scrutiny. The latter course is followed in this Note.

93. See, e.g., CAL. WELF. \& INST'NS CODE $\$ 5150$ (West 1972). See generally BRAKEL \& Rock, supra note 1 , at 72-76 (Table 3.2). 
in enacting this law is simply to ensure public safety, the statute is plainly underinclusive and thus, under the applicable standard, invalid. Indeed, the classification is arguably so arbitrary as perhaps to fail to survive the rational relation test to which classifications which are not suspect are subjected. ${ }^{94}$ As long as the dangerousness standard is a constant, dangerous persons not mentally ill are by definition just as dangerous (as a group) as dangerous persons who are mentally ill. Thus, if protecting the populace is the only goal of the statute, then institutionalizing only mentally ill dangerous persons does not logically follow.

The state can, however, advance a secondary purpose; the classification may then be more defensible. For example, the state might claim that the statute seeks to reach only dangerous persons who can be treated for their dangerous proclivities (and thereby restored to upright, productive citizens). This decision about allocating the state's resources and the classification chosen to implement that decision would arguably be immune from successful attack under the rational connection standard of Railway Express Agency v. New York. ${ }^{95}$ The law could not, however, survive the strict scrutiny mandated for suspect classifications. Since some mentally ill dangerous persons are not treatable $e^{96}$ and some persons dangerous but mentally sound are treatable, ${ }^{97}$ the law is both under- and overinclusive and therefore invalid.

State laws also typically provide for the civil commitment of persons mentally ill and dangerous to themselves. ${ }^{98}$ If the state's purpose is simply to protect people from seriously injuring themselves, the

94. But see Railway Express Agency v. New York, 336 U.S. 106, 110 (1949). ("It is no requirement of equal protection that all evils of the same genus be eradicated or none at all.")

95. Id. See note 7 supra.

96. See Katz, The Right to Treatment-An Enchanting Legal Fiction?, 36 U. CHI. L. REv. 755, 779 (1969). On the untreatable patient generally, see Note, Conditioning and Other Technologies Used to "Treat?" "Rehabilitate?" "Demolish?" Prisoners and Mental Patients, 45 S. CAL. L. REv. 616, 652 (1972). [hereinafter cited as Note, Conditioning and Other Technologies]; Note, Hospitalization of Mentally Ill Criminals in Pennsyl. vania and New Jersey, 110 U. PA. L. REV. 78, 85-88 (1961).

97. Cf. Singer, Psychological Studies of Punishment, 58 CaLIF. L. REv. 405, 433 (1970):

Given the time and the resources, a behavior therapy program could make a bank robber want to vomit every time he saw a bank, could make an armed robber shudder every time he saw a gun. As experimenters have successfully conditioned verbal and imaginal stimuli, such a program could also induce these reactions whenever the convicted thief even thought or talked about guns and banks.

For a survey of the various modern techniques of behavior control, see Note, Conditioning and Other Technologies, supra note 96, at 616-33. On the potential for individual and societal metamorphosis in these techniques, see generally J. Descado, PhysicaL

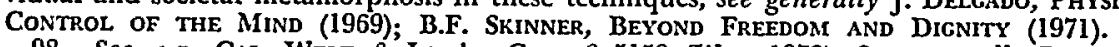

98. See, e.g., CAL. WELF. \& INST'NS CODE $\$ 5150$ (West 1972). See generally BRAKEL \& Rock, supra note 1, at 72-76 (Table 3.2). 
classification would not even seem to qualify as rational, ${ }^{90}$ for we legislators, working hard and long hours, may be just as dangerous to ourselves as they, with their deranged mental condition, are to themselves. ${ }^{100}$ Such a law is simply far too underinclusive to withstand strict scrutiny. Moreover, whether the state, coming forward with a secondary objective, could rescue the law from invalidation seems dubious. The treatment rationale suggested earlier, i.e., we (legislators) only want to detain those (the mentally ill) who can be treated for their condition, is no more satisfactory in this context than in the previous one. The state might allege, however, that its purpose is to treat those who need treatment but are unable to make a reasoned decision to seek or not to seek such treatment: Again, the mental illness classification would fall. On the one hand, the mentally ill are not uniformly characterized by an inability to make a rational decision to seek treatment; some seek voluntary commitments. The classification is thus overinclusive. On the other hand, normality is no guarantee of objective decisionmaking abilities. For example, "normal" persons often postpone a visit to the doctor until after an important business trip or a primary race even though an objective third party would recognize the immediate necessity of medical attention. The classification is, then, also underinclusive and the law fails on both counts.

A third commitment statute found in many states is one authorizing the detention of any person mentally ill and in need of treatment. ${ }^{101}$ The treatment objective is patent: We want to improve their mental state in order to leave them better and happier persons. Yet, to be consistent with this benign objective, the legislature should extend its beneficence to all persons who fail to live and act as society knows would be in their best interests. The patent imprecision of this underinclusive classification would trigger its demise under strict scrutiny.

It warrants emphasis, furthermore, that the state will be unable to salvage these commitment laws by asserting a panoply of addi-

99. See note 94 supra.

100. See In Memory of Mr. Justice Jackson. 349 U.S. XXVII, XXVIII-XXIX (1955) (resolutions delivered by Solicitor General Sobeloff):

Associate Justice Robert Houghwout Jackson died suddenly of a heart attack on Saturday, October 9,1954, at the age of sixty-two and at the height of a brilliant judicial career. . . Justice Jackson had suffered a previous attack in the spring of 1954. - . His doctors gave him the choice between years of comparative inactivity or a continuation of his normal activity at the risk of death at any time. With characteristic fortitude he chose the second alternative.

101. See, e.g., PA. STAT. ANN. tit. 50, $\$ 406$ (West 1969). See generally BrakEL \& Rock, supra note 1, at 72-76 (Table 3.2). 
tional purposes. Reflection on the stereotypical nature of the classification process should satisfy any doubts on the matter. Basically, in classifying, "mental illness" serves as a shorthand for various goalrelated characteristics-e.g., dangerousness, need for treatment, dependence-no one nor combination of which comprises a sufficiently precise definition of the mentally ill. On the one hand, no goalrelated characteristic or characteristics exclude all persons not mentally ill; on the other, no such characteristic or characteristics embrace all persons mentally ill. Every goal asserted by the state to justify the classification, then, bears within it the seed of over- and underinclusiveness with regard to the class of mentally ill persons. Combinations of goals simply fail to vindicate the classification in varying degrees of over- and underinclusiveness. The burden of proof placed on the state when it employs a suspect classification, therefore -to demonstrate sheer perfection in classification or show temporal justification for any imperfection-could not be met by ingenuity in enumerating legislative goals. Accordingly, without necessarily impugning the state's honesty in its elucidation of goals, a court would almost inevitably find that the state has not established the validity of its suspect classification.

\section{b. Possible Reformulations of Commitment Standards}

That current statutes would be invalid should not be understood to imply that legislatures are impotent to promote by new legislation any of the lawful state objectives informing the old laws. Legislatures would simply be denied authority to classify on the basis of mental illness to serve those goals. Thus, if the legislature's purpose is to safeguard the public from dangerous persons, it must classify on the basis of dangerousness. It must authorize the detention of all dangerous persons, whether mentally ill or not. Although such a law would survive scrutiny under the test proposed in this Note, it might be politically unacceptable. This obstacle to the enactment of a law which reaches all dangerous persons underlines a crucial role of the Equal Protection Clause: to expose legislative purposes to public scrutiny, a scrutiny customarily missing when laws affect only the voiceless in society. As stated so well by Mr. Justice Jackson in his Railway Express concurrence:

[T] here is no more effective practical guaranty against arbitrary and unreasonable government than to require that the principles of law which officials would impose upon a minority must be 
imposed generally. Conversely, nothing opens the door to arbitrary action so effectively as to allow those officials to pick and choose only a few to whom they will apply legislation and thus to escape the political retribution that might be visited upon them if larger numbers were affected. Courts can take no better measure to assure that laws will be just than to require that laws be equal in operation. ${ }^{102}$

If society demands preventive detention of all dangerous persons, it will reelect legislators who enact preventive detention statutes. If society is not willing to countenance so all-embracing a measure, however, the Equal Protection Clause proscribes legislative efforts to detain only those dangerous persons who also happen to be mentally ill.

To limit the class of persons affected by the law, the legislature might consider injecting a treatment rationale into the picture. The statute would then reach only persons dangerous and treatable for their dangerousness. Mental illness would not be the basis for commitment nor would normality be an exemption from commitment. The legislature might well decide, however, that the costs of administering such a law would outweigh its benefits. Alternatively, if the public strongly opposed involuntary commitment of those not mentally ill, the legislature might also choose not to enact such a law. In any event the legislature would be forced to face hard questions which it had previously avoided by employing a suspect classification and to shape its means more discriminately to effect its ends. ${ }^{103}$

A valid statute designed to reach persons "dangerous to themselves" could also be formulated, but it, too, would have to differ dramatically from its predecessors. If the state's objective is to protect people from their own tendencies which seriously endanger their physical well-being, the law must cover many people whom society would almost certainly not want to commit involuntarily. The businessman too ready to sacrifice health for money, the judge too overzealous in his public service, the mountain-climber unable to contain his urge to climb still higher-they and many others all might be fit subjects for commitment. Indeed, we as legislators might find our-

102. 336 U.S. 106, 112-13 (1949) (Jackson, J., concurring).

103. The conclusive presumption cases raise similar considerations and require analogous remedies. See, e.g., Cleveland Bd. of Educ. v. La Fleur, 94 S. Ct. 791 (1974); Vlandis v. Kline, 412 U.S. 441 (1973); Stanley v. Illinois, 405 U.S. 645 (1972); Bell v. Burson, 402 U.S. 535 (1971) The principal difference between conclusive presumption and suspect classification is that the latter disallows imperfect legislative classification, while the former allows such imperfection provided an opportunity is afforded at the administrative level for individuals to argue the imperfection as applied to them. 
selves in danger of losing our freedom. On the other hand, if the legislature's purpose is to protect from themselves only those people who are incompetent to decide whether to expose themselves to a risk of serious physical harm, the law need take in a much smaller class of persons. Thus tailored, the statute would almost surely receive public approbation. The mental illness classification would be erased and a more discriminating one, one precisely fitted to the legislative goal, placed in its stead. ${ }^{104}$

To be politically acceptable any statute which is aimed at persons "in need of treatment" and which does not classify on the basis of mental illness would probably have to be tailored along similar lines. Unless the legislative purpose is narrowed to "improving" only those incompetent to decide for themselves the desirability of such self-improvement, the law enacted would have to embrace a substantial portion of society. ${ }^{105}$

\section{c. Implications of Strict Scrutiny and Reformulated Standards for Other Aspects of the Commitment Process}

Strict scrutiny of commitment statutes would force the revision of many of their procedural provisions. Presently, Baxstrom v. Herold ${ }^{100}$ is the principal authority for judicial expansion of the procedural safeguards due those whom the state tries to commit. Read most liberally, Baxstrom would require the state to grant similar procedural rights in all settings in which similar issues are decided. The demanding test activated by declaring mental illness to be a suspect classification would give certainty to the validity of this ex-

104. The underinclusiveness of mental illness classifications is thus the primary focus in this reformulation process. Legislatures are forced to impose generally those standards which they had previously imposed on only the mentally ill; cf. pp. 1263-64 supra. Overinclusiveness is relevant, however, insofar as it evidences (1) the tendency of the we-group to underestimate the increase in fairness to the mentally ill from more precise classification, and (2) the readiness of the we-group to classify in a manner which affirms "our" distance from "them." See pp. 1250-51 supra.

105. The viability of other lines of constitutional attack on these revised statutese.g., due process, cruel and unusual punishment-is a matter beyond the scope of this Note.

106. 383 U.S. 107 (1966). In Baxistrom the Court reviewed New York procedures for the civil commitment of persons at the expiration of a prison term. In accordance with state law petitioner Baxstrom was civilly committed at the end of his two-and. a-half to three year term without the bencfit of a jury trial, which is allowed all other classes of persons who challenge their commitments. Additionally, by administrative decision Baxstrom was placed in a hospital maintained by the Department of Corrections rather than a civil hospital; committed persons in any other class could be sent to the Department of Corrections hospital only after a judicial proceeding in which it was determined that they were too dangerous to be left in a civil hospital. The Court held both classifications to be arbitrary and extended the same process to Baxstrom and others committed at the end of their prison terms as granted to all other persons for these issues. 
pansive reading of Baxstrom insofar as commitment procedures for the mentally ill are concerned. Consider, for example, commitment procedures under a law authorizing preventive detention of all dangerous persons. (The previous "mentally ill and dangerous" statute has long since been declared unconstitutional.) A procedural statute prescribing different processes for committing persons dangerous and mentally ill as opposed to persons dangerous and not mentally ill would almost certainly not survive strict scrutiny. Thus, a jury trial might in general be more emotionally disruptive to those dangerous persons who are also mentally ill. Yet, the state cannot, in ostensibly attempting to protect the defendant in a dangerousness hearing, classify on the basis of mental illness in granting the right to a jury trial. Such a generalization fails to supply the perfection demanded, absent unusually pressing circumstances, by the strict scrutiny standard.

Invalidation of such a law would leave the state with three options. If the state still wants to permit some jury trials, it would have to single out, almost necessarily on a case-by-case basis, those persons whose well-being would be most threatened by a jury trial. Since such case-by-case determinations might well prove more costly than simply awarding a jury trial to everyone, the state might instead opt for the latter proposal. On the other hand, the state might simply decide to deprive everyone, mentally ill and sound alike, of the right to a jury trial in a dangerousness hearing. This deprivation might be an unconstitutional denial of due process. ${ }^{107}$ Whatever the prospects of success for a due process challenge, however, suspect classification theory has served its purpose: It has forced the legislature to weigh the desirability of imposing a principle of law on some of "us." Similar procedural consistency would, of course, be required in committing persons under revised "dangerous to self" or "in need of treatment" statutes, though a state could presumably impose a different commitment procedure for each statute.

Once committed under one of the revised statutes, persons who are also mentally ill could not, on the basis of that fortuity, be deprived of privileges or comforts enjoyed by those not mentally ill. Treatment, where that was a basis for commitment, must be given according to what this patient requires to alleviate or cure the condition that warranted his commitment. ${ }^{108}$ Finally, as with com-

107. Cf. Goldberg v. Kelly, 397 U.S. 254 (1970).

108. On the right to treatment generally, see 1 Legal Rights of THE MIENTALLY Handicapped 275-92 (B. Ennis \& P. Friedman eds. 1973); Katz, supra note 96; Notc, Givil Restraint, Mental Illness and the Right to Treatment, 77 YALE L.J. 87 (1969). The outer limit of judicial activism on this matter thus far is represented by Wyatt v. Stickney, 344 F. Supp. 373, 387 (M.D. Ala. 1972). 
mitment procedures and for the same reasons, the procedures for termination of commitment under a given commitment statute would have to be the same for those mentally ill and those not.

\section{Laws Regulating Matters Other Than Commitment}

Laws other than those governing the civil commitment of the mentally ill would also be significantly affected by strict scrutiny. Laws under which mental illness is a ground for trade license revocation ${ }^{109}$ would be struck down. If the legislature wants to ensure occupational fitness, it cannot simply make mental illness a shorthand for unfitness. Even if most mentally ill persons might be unfit to perform a certain trade, the crudeness of the classification underlying such a license revocation standard would require the law's invalidation. Also unconstitutional would be statutes depriving mentally ill persons of the right to vote. ${ }^{110}$ The legislature may, of course, promote informed, rational exercise of the ballot, but its classification on the basis of mental illness is demonstrably over- and underinclusive. In pursuing this goal the state would have to be far more discriminating in its selection of means. Whether mental illness is an adequate basis for denying a person the right to manage his property and property interests ${ }^{111}$ also seems dubious. Even assuming that most mentally ill people are, as a result of their illness, incompetent to manage property, some undoubtedly are competent to do so; and similarly, even assuming that most persons not mentally ill are competent to perform this task, some undoubtedly are not. Like the licensing and voting statutes described above, these property laws classifying on the basis of mental illness would fail for their overand underinclusiveness.

Similarly in danger of invalidation would be statutes which make mental illness a ground for divorce or annulment, ${ }^{112}$ sanction sterili-

109. See, e.g., Conn. Gen. Stat. Ann. $\$ 20-59$ (West 1958). See generally BrakeL \& Rock, supra note 1, at 326-32 (Table 9.3).

110. See, e.g., Conn. Gen. Stat. Ann. \$ 9-12 (West 1958). See generally Brakel \& Rock, supra note 1, at 333-39 (Table 9.4).

111. See, e.g., CaL. Civ. Code \$ 39l (West 1954). See generally Brakel \& Rock, supra note 1, at 315-25 (Tables 9.1, 9.2). Insofar as a statute provides for the withdrawal of certain property rights upon a determination that one is incompetent to exercise them, no problems of suspect classification are implicated. But the legislature cannot single out the mentally ill as a class incompetent to manage property interests even if it allows an opportunity for rebuttal by individual members of the class at the administrative level. On this contrast between suspect classification and conclusive presumption requirements, see note 103 supra.

112. See, e.g., Conn. Gen. Stat. Ann. § 46-19 (West 1958). See generally Brakel \&. Rock, supra note 1, at 244-47 (Table 7.2). 
zation of mentally ill persons deemed likely to pass on to offspring an inherited tendency to mental illness, ${ }^{113}$ and disqualify the mentally ill from jury duty. ${ }^{114}$ Such laws classifying on the basis of mental illness would fall unless the state could demonstrate that the classification is perfect or at least as precise as the time for its formulation allowed. Strict scrutiny would therefore almost always force the legislature to choose between serving its goals by unsuspect classifications covering some of "us" and not serving these goals at all.

IV. The Burger Court and Suspect Classifications: Resolving an Untimely Disinheritance

A constitutionally-based revolution in laws affecting the mentally ill would thus follow from adding the mental illness classification to the ranks of the suspect. But the Court's reluctance of late to create any new suspect classifications would appear to make such a judicially mandated metamorphosis unlikely.115 Perhaps, however, the Court can be persuaded to change its ways.

First of all, the Court's reluctance to continue along the constitutional path which it appears to have marked out for itself is probably ill-founded. As one commentator on the 1971 term has argued, ${ }^{110}$ the Court's failure to add to the number of suspect classifications derives from its distaste for substantive testing: The Court would like, he asserts, to avoid commitments to inquire into how compelling the asserted state interest is (and then, if it finds the interest sufficiently compelling, into whether less restrictive alternatives are available). But if this explanation of the Court's recent decisions is correct, ${ }^{117}$ the Court has acted upon mistaken premises in at least

113. See, e.g., Mich. Comp. LAws ANn. \$\$ 720.301, 720.301 (West 1968). See gent'rally Brakel \& Rock, supra note 1, at 220-23 (Table 6.1).

114. See, e.g., Conn. Gen. Stat. Ann. \$\$ 9-12 (W'est 1958), $51-217$ (Supp. 1973). See generally BRAKEL \& Rock, supra note 1, at 333-39 (Table 9.4).

115. Indeed on one occasion, Reed v. Reed, 404 U.S. 71 (1971), the Court appearcd to go to great lengths to avoid adding any more classifications to the suspect list; $c f$. Frontiero v. Richardson, 411 U.S. 677, 691-92 (1973) (Stewart \& Powell, JJ., concurring).

116. Gunther, supra note 11. For a sense of the still evolving nature of the doctrinc, compare San Antonio Independent School Dist. v. Rodriguez, 411 U.S. 1, 18-39 (1973), and Frontiero v. Richardson, 411 U.S. 677 (1973) (plurality opinion), with San Antonio Independent School Dist. v. Rodriguez, supra at 98-110 (Marshall, J., dissenting), and Frontiero v. Richardson, supra at 691-92 (Stewart \& Powell, JJ., concurring).

117. There is language in some of that term's cases to support Gunther's analysis of the Court's thinking. The Court's explicit disclaimer of substantive testing in Eisenstadt v. Baird, for example, appears to witness its general hypersensitivity to such activity: Of course, if we were to conclude that the Massachusetts statute [prohibiting distribution of contraceptives to single persons] impinges upon fundamental freedoms 
some cases, for, as argued earlier, by declaring a classification suspect, the Court would not, under its past holdings, bind itself to test for a compelling state interest in future decisions. It need only analyze the perfection of the classification; it need not second-guess legislatures as to the importance of the asserted lawful purposes.

Secondly, the Court's adoption of a sliding-scale rationality standard may indicate that a Court cognizant of the nonsubstantive orientation of suspect classification scrutiny would prove far more willing than now to create new suspect classifications. This is not to deny that the admission of a new classification to the suspect circle would run counter to the trend established by the Court's recent equal protection decisions; rather, the contention is that, once the implications of such a move are properly understood, it will be seen to be consistent with the rationale informing this latest line of cases. Basically, then, the Court's development of the sliding-scale test seems to demonstrate a desire on its part to force legislatures to fashion classifications perfectly fitted, or nearly so, to their purposes. The Court has apparently taken to heart the wise counsel of $\mathrm{Mr}$. Justice Jackson that "there is no more effective practical guaranty against arbitrary and unreasonable government than to require that the principles of law which officials would impose upon a minority must be imposed generally." 118

By demanding laws "equal in operation,"119 a court thus enlarges the potentially affected public and thereby increases the likelihood that these laws will receive careful public scrutiny. The politically impotent they-group would then find politically potent allies with a personal stake in disputing legislative goals, a result that bears a crucial relation to the Court's reluctance to perform substantive testing itself. If the Court indeed wants to forge a viable alternative to substantive testing by the judiciary, the ostensible logical underpinning of its new sliding-scale formula, it would only be appropriate for it to add to the list of suspect classifications. When the voiceless they-group alone is affected, there may be no other voices heard. The Court has never charged itself with defending politically im-

under Griswold, the statutory classification would have to be not merely rationally related to a valid public purpose but necessary to the achievement of a compelling state interest.

405 U.S. 438, 444 n.7 (1972) (dictum) (emphasis in original). But cf. Roe v. Wade, 410 U.S. 113 (1973); Ely, The Wages of Crying Wolf, supra note 37.

118. Railway Express Agency v. New York, 336 U.S. 106, 112 (1949) (Jackson, J., concurring).

119. Id. at 113 . 
potent they-groups from legislative ends, and perhaps rightly so. ${ }^{\mathbf{1 2 0}}$ But consistency with its construction of the Equal Protection Clause in the past seems to require that the Court create spokesmen to argue the outsider group's case in the political arena. In developing sliding-scale rationality, the Court has intimated a willingness to accept this latter role. The Court could admirably affirm its assumption of that role and its adherence to the unarticulated principles that appear to inform its suspect classification decisions by declaring mental illness a suspect classification.

120. See pp. 1251-52 supra. 